\title{
ASUHAN KEPERAWATAN PADA Tn. D DENGAN ISOLASI SOSIAL DIRUANG MERAK RUMAH SAKIT JIWA Dr. SOEHARTO HEERDJAN JAKARTA
}

\author{
Ns. Nelwetis ${ }^{1}$ \\ D-3 Keperawatan Politeknik Karya Husada Jakarta ${ }^{1}$ \\ Jl. Ciputat Raya No. 36 Pondok Pinang, Jakarta - Selatan ${ }^{l}$ \\ Email : akper_khj_2005@yahoo.co.id ${ }^{l)}$
}

\begin{abstract}
ABSTRAK
Setiap individu mempunyai potensi untuk terlibat dalam hubungan sosial pada berbagai tingkat hubungan yaitu dari hubungan intim bisa saling berhubungan, keintiman dan saling ketergantungan dalam menghadapi dan mengatasi berbagai kebutuhan setiap hari. Individu tidak akan mampu memenuhi kebutuhan hidupnya tanpa adanya hubungan dengan lingkungan social. Oleh karena itu individu perlu membina hubungan interpersonal yang memuaskan. Tujuan umum penelitian ini adalah melakukan asuhan keperawatan pada klien dengan Isolasi Sosial. Penelitian ini menggunakan metode deskriptif. Tekhnik yang digunakan dalam mengumpulkan data, menganalisa data serta menarik kesimpulan yang kemudian disajikan dalam bentuk narasi. Cara menyusun laporan penelitian ini adalah Study Kepustakaan dan Study Kasus. Setelah melakukan Asuhan Keperawatan penulis mendapatkan 5 diagnosa : Isolasi Sosial, Harga Diri, Koping Keluarga Inefektif, Regimen Theraupetik Inefektif, dan Resiko Gangguan Sensori Persepsi. Intervensi yang dilakukan untuk diagnosa utama yaitu isolasi sosial adalah Sp-I bina hubungan saling percaya, identifikasi penyebab Isolasi social, diskusikan tentang keuntungan berinteraksi dengan orang lain, dan kerugian tidak berinteraksi dengan orang lain, ajarkan cara berkenalan, beri pujian kemampuan yang dimiliki. Sp-II anjurkan klien untuk mempraktekkan cara berkenalan dengan satu orang, evaluasi kegiatan harian klien, Sp-III evaluasi jadwal kegiatan klien, anjurkan klien untuk memperaktekkan cara berkenalan dengan dua orang atau lebih. Implementasi yang dilakukan 1 yaitu: Isolasi Sosial dengan cara: Sp-I membina hubungan saling percaya antara perawat dan klien, mengidentifikasikan penyebab Isolasi Sosial Pasien, mendiskusikan dengan klien keuntungan berinteraksi dengan orang lain dan kerugian tidak berinteraksi dengan orang lain, mengajarkan cara berkenalan, Sp-II yaitu memberikan kesempatan pada klien untuk mempraktekkan cara berkenalan dengan satu orang, menganjurkan klien memasukkan kegiatan kedalam jadwal harian. Sp III yaitu memberikan kesempatan pada klien untuk memperaktekkan cara berkenalan dengan dua orang atau lebih, memasukkan kegiatan yang dilakukan kedalam jadwal kegiatan harian. Evaluasi yang dapat dicapai dari hasil tindakan keperawatan adalah hubungan saling percaya antara perawat dan klien, klien dapat dapat menyebutkan penyebab Isolasi Sosial, menyebutkan keuntungan berinteraksi dengan orang lain dan kerugian tidak berinteraksi dengan orang lain. Klien dapat mempraktekkan cara berkenalan dengan satu orang. Klien dapat memperaktekkan cara berkenalan dengan dua orang, klien dapat memasukkan kegiatan kedalam jadwal harian apa yang sudah diajarkan dan dilakukan.
\end{abstract}

Kata Kunci : Isolasi Sosial, Harga Diri, Koping Keluarga Inefektif, Regimen Theraupetik Inefektif, Resiko Gangguan Sensori Persepsi

\section{A. PENDAHULUAN}

\section{Latar Belakang}

Setiap individu mempunyai potensi untuk terlibat dalam hubungan social pada berbagai tingkat hubungan yaitu dari hubungan intim bisa saling berhubungan, keintiman dan saling ketergantungan dalam menghadapi dan mengatasi berbagai kebutuhan setiap hari. Individu tidak akan mampu memenuhi kebutuhan hidupnya tanpa adanya hubungan dengan 
lingkungan social. Oleh karena itu individu perlu membina hubungan interpersonal yang memuaskan.

Kepuasan hubungan dapat dicapai jika individu terlibat secara aktif dalam proses berhubungan. Peran serta yang tinggi dalam hubungan disertai respon lingkungan yang positif akan meningkatkan rasa memiliki, kerja sama, hubungan timbal balik yang sinkron. Peran serta dalam proses hubungan dapat berfluktuasi sepanjang rentang tergantung (dependen) dan mandiri (independen), artinya suatu saat individu tergantung pada orang lain dan suatu saat orang lain tergantung pada individu. Pemutusan proses hubungan terkait erat dengan ketidak puasan individu terhadap proses hubungan yang disebabkan oleh kurangnya peran serta, respon lingkungan yang negatif. Kondisi ini dapat mengembangkan rasa tidak percaya diri dan keinginan untuk menghindar dari orang lain. Salah satu bentuk gangguan jiwa adalah gangguan berhubungan dengan orang lain.

Berdasarkan data dan keterangan dari ruang Merak, Rumah Sakit Jiwa Dr. Soeharto Heerdjan Jakarta, pada bulan Januari-Juni 2010, dari 226 pasien di ruang Merak, terdata 36 orang $(16,0 \%)$ yang mengalami Isolasi Sosial : menarik diri, halusinasi 129 orang $(57,1 \%)$ Harga diri rendah12 orang $(5,3 \%)$ dan Resiko prilaku kekerasan 49 orang $(21,6 \%)$.

Begitu luasnya permasalahan dan mengingat pentingnya peran perawat sebagai promotif, preventif, curativ, dan rehabilitative maka penulis ingin melaksanakan peran perawat yaitu sebagai pelaksana asuhan keperawatan, karena apabila klien dengan Isolasi Sosial tidak segera diatasi, maka akan menyebabkan terjadinya halusinasi, curiga, mencederai diri - sendiri atau orang lain. Oleh karena itu penulis tertarik untuk mengambil judul "Asuhan Keperawatan Pada Tn.D Dengan Isolasi Sosial di Ruang Merak Rumah Sakit Jiwa Dr. Soeharto Heerdjan Jakarta."

\section{Tujuan Penelitian}

Tujuan umum penelitian ini adalah melakukan asuhan keperawatan pada klien dengan Isolasi Sosial. Sedangkan tujuan khususnya adalah : Mampu melakukan pengkajian, menentukan masalah keperawatan, merencanakan tindakan keperawatan pada klien dengan Isolasi Sosial, serta mampu melakukan evaluasi sebagai hasil tindakan keperawatan yang telah diberikan pada klien dengan Isolasi Sosia. Selain itu diharapkan mampu mengidentifikasi kesenjangan antara teori tentang Isolasi Sosial dengan kenyataan yang ada, serta mendokumentasikan seluruh kegiatan keperawatan yang telah dilakukan.

\section{Ruang Lingkup}

Ruang lingkup penelitian ini adalah Asuhan Keperawatan pada kasus Tn. D dengan Isolasi Sosial yang dilaksanakan di Ruang Merak, Rumah Sakit Jiwa Dr. Soeharto Heerdjan Jakarta.

\section{Metode Penelitian}

Penelitian ini menggunakan metode deskriptif. Tekhnik yang digunakan dalam mengumpulkan data, menganalisa data serta menarik kesimpulan yang kemudian disajikan dalam bentuk narasi. Cara menyusun laporan penelitian ini adalah Study Kepustakaan, dan Study Kasus 


\section{B. TINJAUAN KASUS}

\section{Pengkajian}

Pengkajian merupakan tahap awal dan dasar utama dari proses keperawatan. Dengan tujuan untuk mengumpulkan data - data dengan cara wawancara observasi langsung dengan klien, informasi dari catatan keperawatan, catatan medis dan perawat ruangan.

a. Identitas Klien. Klien Tn.D berusia 34 tahun, jenis kelamin laki - laki, status perkawinan klien Duda, Agama Islam, Suku Sunda, pendidikan terakhir SD, klien bertempat tinggal di Kp,BejongRt 10/04 Bejong Kec.Cikupa Tangerang Banten, Klien dirawat pada tanggal 26 Mei 2010 di Rumah Sakit Dr. Soeharto Heerdjan. Nomor Rekam Medik 00.97. Sumber informasi yaitu klien, perawat ruangan dan status rekam medik

b. Alasan Masuk. Klien masuk Rumah Sakit Dr. Soeharto Heerdjan pada tanggal 26 mei 2010 di antar oleh keluarganya karena di rumah mengurung diri terus di kamar,klien tidak mau berinteraksi drngan orang lain,klien mengatakan malu untuk berinteraksi dengan orang lain karena klien tidak punya kemampuan apapun,dan klien mengatakan kurang di hargai oleh keluarganya.

c. Faktor Predisposisi. Klien masuk ke Rumah Sakit Dr. Soeharto Heerdjan untuk yang ke dua kalinya, pertama klien masuk pada bulan Mei 2008 di Rumah Sakit Jiwa Dr.Soeharto Hearjan jugai, masuk yang ke dua kalinya pada tanggal 26 Mei 2010 sampai dengan sekarang di Rumah Sakit Dr. Soeharto Heerdjan, klien sering keluar masuk karena pengobatan sebelumnya kurang berhasil, dalam keluarga klien tidak ada anggota klien yang mengalami gangguan jiwa dan klien kurang mendapat dukungan atau perhatian dari keluarga. Masalah Keperawatan : Penatalaksanaan Regime Terapeutik Inefektif, dan Koping keluarga inefektif

d. Klien mempunyai pengalaman yang tidak menyenangkan yaitu klien telah gagal dalam membina hubunagan rumah tangga,klien mengatakan sudah bercerai dendan istrinya. klien mengatakan sekolah hanya lulus SD karena klien tidak punya biaya untuk melanjutkan sekolah, klien mengatakan malu untuk bergaul dengan sebayanya karena teman-temanya sudah kerja semua sedangkan dia hanya mengembala kambing. Masalah Keperawatan : Harga Diri Rendah dan Isolasi sosial

e. Pemeriksaan Fisik. Setelah dilakukan pemeriksaan fisik pada saat pengkajian di dapat data dengan hasil tanda - tanda vital yaitu tekanan darah $120 / 80 \mathrm{mmHg}$, suhu $36,0^{\circ} \mathrm{C}$, nadi 80 kali per menit dan pernafasan 18 kali per menit. Hasil ukur berat badan $55 \mathrm{~kg}$, tinggi badan $165 \mathrm{~cm}$. Klien mengatakan tidak ada keluhan fisik. Masalah Keperawatan : Tidak ada masalah keperawatan

\section{f. Psikososial}

a) Genogram. Klien mengatakan merupakan anak kelima dari tujuh bersaudara,klien mengatakandirumah tinggal sama empok dan adik,klien mengatakan sering dimarahi sama adeknya,klien mengatakan sudah bercerai dengan istrinya dan anaknya dibawa sama istrinya,klien mengatakan di rumah hanya mengembala kambing. Masalah Keperawatan : Koping keluarga inefektif dan Regimen terapeutik inefektif 
b) Konsep Diri

1.Gambaran diri. Klien mengatakantidak berguna. Klien mengatakan takut mati. Klien mengatakan yang disukai dari dirinya adalah tai lalat di dadanya.

2.Identitas. Klien mampu menyebutkan nama,dan alamatnya. Klien mengatakan tinggal sama emak dan adiknya. Klien mengatakan puasdan seneng menjadi cowok

3.Peran. Klien merupakan anak kelima daritujuh bersaudara. Klien mengatakan di rumah hanya menggembala kambing. Klien mengatakan sering dimarahin sama adiknya.

4.Ideal diri. Klien mengatakan pengen sembuh total,klien mengatakan pengen ketemu sama anaknya,dan pengen berkumpul dengan keluarganya

5.Harga diri. Klien mengatakan jarang bergaul dengan teman teman sebayanya karena malu klien tidak punya kemampuan apapun,klien mengatakan kurang di hargai sama keluarganya. Masalah Keperawatan : Harga Diri Rendah

a.Hubungan Sosial. Klien mengatakan orang yang berharga saat ini adalah empoknya yang paling tua karena dia yang paling perhatian sama klien. Klien mengatakan tidak pernah mengikuti kegiatan yang ada di lingkungan rumahnya,tapi di rumah sakit klien ikut pengajian dan terapi aktifitas kelompok (TAK). Klien mengatakan malas bergaul dengan orang lain karena klien lebih senang sendiri,klien tampak menyendiri. Masalah Keperawatan : Isolasi Sosial

b.Spiritual. Klien mengatakan nilai dan keyakinan sangat penting dan klien memeluk agama islam, klien mengatakan jarang solatkarena tidak punya sarung,klien mengatakan ikut pengajian. Masalah Keperawatan : Tidak ada masalah

\section{g. Status mental}

a) Penampilan. Penampilan klien tanpak rapi,dan penggunaan pakean normal atau sesue dengan jenis kelamin klien,klien mau melakukan perawatan dirinya tanpa dimotivasi oleh pearawat seperti ganti paken sendiri. Masalah Keperawatan : Tidak ada masalah

b) Pembicaraan. Pada saat berkomunikasi klien berbicara lambat dan tidak mampu memulai pembicaraan, klien hanya menjawab pertanyaan seperlunya saja. Masalah Keperawatan : Isolasi Sosial

c) Aktivitas motorik. Klien tampak lesu dan gelisah. Masalah Keperawatan : Isolasi Sosial

d) Alam perasaan. Klien mengatakan sedih karena temanya sedikit, ekspresi wajah klien terlihat agak murung, kontak mata klien kurang. Masalah Keperawatan : Harga Diri Rendah, dan Isolasi sosial

e) Afek. Afek klien tumpul, selama interaksi klien tidakmampu untuk memulai pembicaraan,dan menjawab pertanyaan seperlunya saja. Masalah Keperawatan : Isolasi Sosial

f) Interaksi selama wawancara. Selama interaksi atau wawancara klien tanpak kooperatip, meskipun kadang harus dibantu perawat, kontak mata kurang, kadang - kadang saat bicara klien menunduk dan terkadang memandang perawat. Masalah Keperawatan : Isolasi Sosial dan Harga Diri Rendah

g) Persepsi halusinasi. Klien mengatakan dua minggu yang lalu bila bicara ada suara yang mengakut apa yang dia ucapkan. Pada saat dilakukan pengkajian klien sudah tidak mendengar suara - suara lagi. Masalah Keperawatan : Resiko Gangguan Sensori Persepsi : Halusinasi

h) Proses Fikir. Klien kadang-kadang meminta untuk mengulang pertanyaanyang di tanyakan. Masalah Keperawatan : Tidak ada masalah

i) Isi fikir. Selama dilakukan pengkajian tidak ditemukan waham ataupun fobia. Masalah Keperawatan : Tidak ada masala 
j) Tingkat kesadaran. Kesadaran klien Compos Mentis, pada saat pengkajian tidak ditemukan disorientasi waktu, orang ataupun tempat. Masalah Keperawatan : Tidak ada masalah.

k) Memori. Klien dapat mengingat kejadian - kejadian yang telah lalu baik yang sekarang maupun yang lampau. Klien tidak mengalami gangguan memori baik jangka panjang maupun jangka pendek dan saat ini. Masalah Keperawatan : Tidak ada masalah

1) Tingkat konsentrasi dan berhitung. Klien tidak mampu berkonsentrasi karena klien terkadang memita mengulang pertanyaan yang di tanyakan. Masalah Keperawatan : Tidak ada masalah

m)Kemampuan penilaian. Klien mampu mengambil keputusan yang sederhana seperti memilih makan atau mandi terlebih dahulu. Masalah Keperawatan : Tidak ada masalah

n) Daya tilik diri. Klien menyadari keadaannya dan alasan mengapa dia masuk ke rumah sakit jiwa,dan membutuhkan perawatan. Masalah Keperawatan : Tidak ada masalah

h. Kebutuhan Persiapan Pulang

a) Makan. Klien makan tiga kali sehari sesuai jadwal di rumah sakit. Klien mau menghabiskan makan dan minum yang telah disediakan dengan bantuan minimal.

b) Buang air besar dan Buang air kecil. Klien buang air besar satu kali sehari, buang air kecil lima sampai enamkali sehari dan melakukannya sendiri di kamar mandi.

c) Mandi. Klien biasa mandi dua kali sehari dengan memakai sabun pagi dan sore tanpa bantuan

d) Berpakaian atau berhias. Klien berpenampilan cukup bersih dan rapi, klien biasa mengganti dan memakai baju tanpa dibantu.

e) Istirahat dan tidur. Klien tidur siang kurang lebih 3 jam dari pukul 13.00 WIB sampai 15.00 WIB dan tidur malam kurang lebih 8 jam dari pukul 21.00 WIB sd 05.00 WIB.

f) Penggunaan obat. Penggunaan obat masih diatur oleh perawat, tapi klien sudah tahu bahwa ia mendapat obat tiga kali sehari dengan jumlah obat $2-3$ butir sekali minum.

g) Pemeliharaan kesehatan. Klien mengatakan biaya perawatan rumah sakit menggunakan jamkesmas,dan klien mengatakan datang kontrol sebulan sekali.

h) Kegiatan di dalam rumah. Klien mengatakan di dalam rumah hanya mencuci baju sendiri saja. Klien mengatakan di rumah mengembala kambing,dan klien bila keluar rumah tau jalan pulang. Masalah Keperawatan : Tidak Ada Masalah.

i. Mekanisme Koping. Mekanisme koping klien maladaptif karena bila ada masalah reaksi klien sering melamun dan tidak mampu menyelesaikan masalah sendiri. Masalah Keperawatan : Isolasi Sosial

j. Masalah Psikososial dan Lingkungannya

a) Masalah dengan dukungan kelompok. Klien tidak masuk dalam organisasi kelompok tertentu.

b) Masalah berhubungan dengan lingkungan. Klien mengatakan males untuk beriteraksi dengan orang lain, klien lebih sering menyendiri daripada bergaul dengan orang lain

c) Masalah dengan pendidikan. Klien mengatakan sekolah hanya lulus sampe SD.

d) Masalah dengan pekerjaan. Klien mengatakan malu karena dirumah hanya mengembala kambing.

e) Masalah dengan perumahan. Klien sekarang tinggal serumah dengan emak dan adiknya.

f) Masalah ekonomi. Klien mengatakan malu karena tidak bisa menghasilkan uang.

g) Masalah dengan pelayanan kesehatan. Klien mengatakan sebelumnya pernah dirawat yaitu tanggal 29 bulan mei 2008.

h) Masalah lainnya. Klien mengatakan semiggu yang lalu klien pusing. 
i) Masalah dengan dukungan lingkungan. Kien mengatakan kurang diterima oleh masyarakat karena penyakitnya. Masalah Keperawatan : Isolasi Sosial dan Harga Diri Rendah

k. Pengetahuan Kurang Tentang. Klien mengatakan kurang mengetahui cara mengatasi atau menyelesaikan masalah dengan baik. Masalah Keperawatan : Kurang Pengetahuan tentang perawatannya

1. Aspek Medis. Diagnosa Medis : Schizofrenia Paraniod. Terapi Medis :

a) Haloperidol $(5 \mathrm{mg}) 2 \mathrm{X} 1$ tablet. Indikasi : Pengendalian hiperaktifitas dan pengendalian TIK serta pengucapan vokal. Kontra Indikasi : Hipersensitifitas terhadap obat, insufisiensi hati, ginjal dan jantung serta hipotensi atau hipertensi. Efek Samping : Hipotensi, hipertensi, takikardia, bradikardia, henti jantung , aritmia serta edema paru.

b) Trihexypenidyl (2mg) 2 X 1 tablet. Indikasi : Semua bentuk parkinson. Kontra Indikasi : Hipertrofi prostat atau obstruksi leher kandung kemih, akalasia. Efek Samping : Pusing, mengantuk, hipotensi, takikardia, mulut kering, retensi urin, depresi serta paranoid.

c) Rizodal 2 mg ( $2 \times 1$ tablet ). Indikasi : Schizofrenia akut dan kronik. Kontraindikasi : Gangguan hati dan ginjal. Efek samping : Mengantuk

m. Analisa Data. Inisial Nama : Tn.D., Ruangan : Merak, No RM : 00.97.96. Analisa data dilakukan pada hari Senin, 21juni 2010

\begin{tabular}{|l|l|}
\hline \multicolumn{1}{|c|}{ Data Fokus } & \multicolumn{1}{|c|}{$\begin{array}{c}\text { Masalah } \\
\text { Keperawatan }\end{array}$} \\
\hline $\begin{array}{l}\text { DS : Klien mengatakan : Males berinteraksi dengan orang lain, dan Lebih seneng } \\
\text { sendiri. }\end{array}$ & $\begin{array}{l}\text { ISOLASI } \\
\text { DO : Klien tanpak menyendiri, Klien tanpak sulit memulai pembicaraan, Klien } \\
\text { tanpak bicara pelan dan lamban, Kontak mata klien kurang }\end{array}$ \\
\hline $\begin{array}{l}\text { DS : Klien mengatakan : Skolahnya hanya sampe SD. Malu untuk berinteraksi } \\
\text { dengan orang lain karena klien tidak punya kemampuan apapun } \\
\text { DO : Klien tampak menyendiri, Saat interaksi/wawancara klien kadang-kadang } \\
\text { merundukdan terkadang memandang perawat }\end{array}$ & $\begin{array}{l}\text { HARG DIRI } \\
\text { RENDAH }\end{array}$ \\
\hline $\begin{array}{l}\text { DS : Klien mengatakan : Keluarga belum ada yang datang menjenguk, Jarang } \\
\text { berinteraksi dengan keluarga, Klien mengatakan kurang mendapat perhatiandari } \\
\text { keluarga }\end{array}$ & $\begin{array}{l}\text { Koping } \\
\text { keluarga } \\
\text { inefektip }\end{array}$ \\
$\begin{array}{l}\text { DO : Selama pengkajian tidak bertemu dengan keluarga klien, dan Kluarga tidak } \\
\text { terlihat. }\end{array}$ & \\
\hline $\begin{array}{l}\text { DS : Klien mengatakan : Sebelumnya sudah dirawat di RSJ Dr.soeharto Heardjan, } \\
\text { Masuk pada taggal 26 mei 2010 sampai sekarang }\end{array}$ & $\begin{array}{l}\text { Regimen } \\
\text { therafetik } \\
\text { DO : Berdasarkan buku status klien pada 29 mie 2008pernah dirawat dan sekarang } \\
\text { masuk pada 26 mie 2010 }\end{array}$ \\
\hline $\begin{array}{l}\text { DS : Klien mengatakan : Dua minggu yang lalu bila bicaraada suara yang mengikuti } \\
\text { apa yang dia ucapkan, dan Sekarang sudah tidak mendengarsuara itu lagi } \\
\text { DO : Klien tanpak banyak diam, Klien tanpak sering melamun, }\end{array}$ & $\begin{array}{l}\text { Resiko } \\
\text { gangguan } \\
\text { sensori } \\
\text { persepsi } \\
\text { Halusinasi: } \\
\text { pendengaran }\end{array}$ \\
\hline
\end{tabular}

2. Diagnosa Keperawatan : Isolasi Sosial, Harga diri rendah, Koping keluarga in efektif, Regimen therapetik in efektif, Resiko Gangguan sensori persepsi Halusinasi pendengaran

3. Perncanaan, pelaksanaan, dan Evaluasi.

a. Diagnosa keperawatan I : Isolasi sosial 
Data subyektif: klien mengatakan males berinteraksi dengan orang lain, dan klien mengatakan lebih seneng sendiri. Data obyektif : klien tampak menyendiri, klien tampaksulit memulai pembicaraan, klien tampak bicara pelan dan lamban, dan kontak mata klien kurang. Tujuam Umum(TUM): klien dapat berinteraksi dengan dengan orang lain. Tujuan Khusus(TUK) : klien dapat membina hubungan saling percaya. Kriteria Evaluasi : setelah dilakukan interaksi klien menunjukkan tanda - tanda percaya terhadap perawat seperti ekspresi wajah cerah, tersenyum, mau berkenalan, ada kontak mata, bersedia menceritakan perasaan atau masalah yang sedang dialaminya. Rencana Keperawatan. Bina hubungan saling percaya dengan cara : memberi salam setiap berinteraksi, perkenalkan nama dan tujuan perawat berkenalan, tanyakan nama dan panggil nama kesukaan klien, tunjukan sikap jujur dan menepati janji setiap kali berinteraksi, tanyakan perasaan klien dan masalah yang sedang dihadapi klien, buat kontrak interaksi yang jelas, dan dengarkan dengan penuh perhatian ekspresi perasaan klien

TUK II :Klien mampu menyebutkan penyebab menarik diri dan tanda tanda isolasi sosial. Kriteria Evaluasi :setelah dilakukan interaksi Klien dapat menyebutkan penyebab isolasi sosial dan tanda -tanda isolasi sosial. Rencana Keperawatan

1. Kaji pengetahuan klien tentang prilaku isolasi sosial dan tanda - tanda isolasi sosial

2. Beri kesempatan pada klien untuk mengungkapkan penyebab isolasi sosial.

3. Diskusikan pada klien tentang prilaku isolasi sosial, tanda - tanda serta penyebab yang muncul

4. Beri pujian terhadap kemampuan klien mengungkapkan perasaannya

TUK III :Klien dapat menyebutkan keuntungan berhubungan dengan orang lain dan menyebutkan kerugian bila tidak berhubungan dengan orang lain. Kriteria Evaluasi : setelah dilakukan interaksi Klien mampu : Klien dapat menyebutkan keuntungan berhubungan dengan orang lain seperti : banyak teman, banyak kenalan dan ada teman bicara Klien dapat menyebutkan kerugian bila tidak berhubungan dengan orang lain seperti : sendiri, kesepian dan tidak ada teman untuk bicara

\section{Rencana Keperawatan}

1.Diskusikan dengan klien tentang keuntungan bergaul dengan orang lain dan kerugian bila tidak bergaul dengan orang lain

2.Bantu klien mengidentifikasi kemampuan yang dimiliki klien untuk bergaul dengan orang lain

3.Beri pujian terhadap kemampuan klien mengungkapkan perasaan keuntungan dan kerugian bila tidak bergaul dengan orang lain

TUK IV : Klien dapat melaksanakan hubungan sosial secara bertahap. Kriteria Evaluasi : setelah dilakukan interaksi Klien dapat mendemonstrasikan hubungan sosial secara bertahap dengan klien lain, perawat dan kelompok. Rencana Keperawatan

1.Lakukan interaksi sering dan singkat dengan klien

2.Motivasi atau temani klien untuk berinteraksi ( berkenalan dengan klien, perawat lain) dan beri contoh cara berkenalan yang baik

3.Tingkatkan interaksi klien secara bertahap ( satu klien, dua klien, satu perawat, dua perawat dan seterusnya )

4.Bantu klien melaksanakan aktivitas klien sehari - hari dengan interaksi

5.Fasilitasi hubungan klien dengan keluarga secara terapeutik 
TUK $V$ : Klien dapat mengungkapkan perasaannya setelah berhubungan dengan orang lain. Kriteria Evaluasi : setelah dilakukan interaksi Klien dapat mengungkapkan perasaannya setelah berhubungan dengan orang lain. Rencana Keperawatan :

1.Dorong klien untuk mengungkapkan perasaannya bila berhubungan dan tidak berhubungan dengan orang lain.

2.Diskusikan bersama klien tentang manfaat berhubungan dengan orang lain dan kerugian bila tidak berhubungan dengan orang lain

3.Memberikan pujian atas kemampuan dan keberhasilan klien

TUK VI : Klien dapat memberdayakan sistem pendukung yang ada, keluarga mampu mengembangkan kemampuan klien untuk berhubungan dengan orang lain. Kriteria Evaluasi : setelah dilakukan pertemuan Keluarga dapat menjelaskan cara merawat klien menarik diri dan berpartisipasi dalam perawatan klien menarik diri. Rencana Keperawatan :

1. Beri penyuluhan kesehatan tentang cara merawat klien melalui pertemuan individu secara rutin dan pertemuan keluarga

2. Beri pujian atas hal - hal yang telah dicapai keluarga

TUK VI :Klien dapat menggunakan obat secara benar dan tepat. Kriteria Evaluasi :setelah dilakukan 1 kali interaksi klien dapat menggunakan obat secara benar dan tepat. Rencana Keperawatan : Bantu klien menggunakan obat secara benar dan tepat, serta Anjurkan klien membicarakan efek samping obat yang dirasakan Implementasi pada Senin, 21 juni 2010 pukul 11.30-11.40 WIB. SP I : pertemuan ke 1

a. Membina hubungan saling percaya

b. Mengidentifikasi penyebab isolasi sosial pasien

c. Berdiskusi dengan pasien tentang keuntungan berinteraksi dengan orang lain

d. Berdiskusi dengan pasien tentang kerugian tidak berinteraksi dengan orang lain

e. Mengajarkan pasien cara berkenalan dengan satu orang

f. Menganjurkan pasien memasukkan kegiatan latihan berbincang-bincang dengan orang lain kedalam kegiatan harian

Evaluasi : Subjektif : Klien mengatakan namanya Tn. D, senang berkenalan dengan perawat, sudah mengenal identitas perawat, malas berbicara dengan orang-orang lain, lebih senang menyendiri, serta sudah mengetahui cara berkenalan. Objektif : Klien mau menyebutkan namanya dan mau berjabat tangan dengan perawat, melakukan kontak mata kurang dan hanya menjawab pertanyaan yang diajukan, dapat menyebutkan nama perawat dengan benar, serta menunjukkan cara berkenalan yang telah diajarkan oleh perawat dengan benar tetapi belum mempraktekkannya ke teman klien yang lain, dan saat berinteraksi klien lebih banyak berdiam diri. Analisa : Klien mampu membina hubungan saling percaya dengan perawat, mampu menyebutkan penyebab isolasi social, serta mampu mengulang cara berkenalan dengan satu orang dengan baik seperti berjabat tangan, sebutkan nama,hobi dan alamat. Planning. Perawat melakukan evaluasi jadwal kegiatan harian pasien, serta Lanjutkan SP II, dan Klien dianjurkan untuk mempraktekkan cara berkenalan dengan satu orang, menceritakan perasaan atau masalah yang sedang dialaminya, serta pasien memasukkan kegiatan latihan berbincang-bincang dengan orang lain kedalam kegiatan harian Implementasi pada Selasa, 22 juni 2010. Pukul 08.30-08.41 WIB. SP II : pertemuan ke 2

1. Mengevaluasi jadwal kegiatan harian pasien

2. Memberikan kesempatan pada klien mempraktekkan cara berkenalan dengan satu orang

3. Membantu pasien memasukkan kegiatan berbincang-bincang dengan orang lain sebagai salah satu kegiatan hari 
Evaluasi : Subjektif : Klien mengatakan senang bias berinteraksi atau berkenalan dengan orang lain dengan benar, mengerti dan tahu cara berkenalan dengan satu orang dengan baik. Objektif : klien tampak berkelan dengan satu orang, tampak berjabat tangan,menyebutkan nama,hobi dan alamatnya, serta klien tampak senang bisa berkenalan dengan orang lain, dan mampu menyebutkan nama perawat teman dia berkenalan yaitu harys dari karya husada. Jadwal kegiatan harian klien mengenai cara berkenalan untuk tanggal 21 juni 2010 tampak terisi. Analisa : Klien mampu mempraktekkan cara berkenalan dengan satu orang dengan baik, serta Klien mampu menyebutkan keuntungan berinteraksi dan kerugian bila tidak berinteraksi dengan orang lain. Planning. Perawat melakukan evaluasi jadwal kegiatan harian pasien, dan Lanjutkan interpensi SP III. Sedangkan klien di anurkan untuk melakukan lagi yang sudah di ajarkan yaitu berkenalan dengan satu orang, dan memasukkan kegiatan kedalam kegiatan harian

Implementasi pada Rabu,23 juni 2010 pukul 10.15-10.25 WIB. SP III : pertemuan ke 3

1. Mengevaluasi jadwal kegiatan harian pasien

2. Memberikan kesempatan pada klien mempraktekkan cara berkenalan dengan satu orang

3. Menganjurkan pasien memasukkan dalam jadwal kegiatan harian

Evaluasi : Subjektif : Klien mengatakan perasaanya setelah berinteraksi dengan orang lain biasa- biasa saja, dan Klien mengatakan mengerti cara berkenalan dengan dua orang dengan baik. Objektif : Klien tampak berkenalan dengan dua orang, berjabat tangan, menyebutkan nama,alamat,dan hobi, serta Klien dapat menyebutkan nama dan alamat teman dia berkenalan yaitu ari dan dian dari karya husada. Analisa. Klien mampu untuk berkenalan dengan dua orang dengan baik. Planning. Perawat melakukan evaluasi jadwal kegiatan harian pasien, Lanjutkan interpensi yaitu berkenalan dengan dua atau kelompok secara bertahap, serta Lanjutkan SP IV. Sementara Klien dianjurkan untuk melakukan ulang yang sudah di ajarkan atau yang sudah di lakukan yaitu berkenalan dengan dua orang atau lebih, dan memasukkan kedalam kegiatan harian.

\section{b. Diagnosa keperawatan II :Harga Diri Rendah}

Data subyektif : Klien mengatakan sekolah hanya sampe SD, dan klien mengatakan malu karena di rumah hanya mengembala kambing, Sementara Data obyektif : klien tampak menyendiri, dan saat interaksi/wawancara klien kadang-kadang merunduk

Tujuam Umum(TUM) :klien memiliki konsep diri yang positip. Tujuan Khusus(TUK) 1 :klien dapat membina hubungan saling percaya. Kriteria Evaluasi : Ekspresi wajah bersahabat,menunjukkan rasa seneng,ada kontak mata,mau berjabat tangan, mau menyebutkan nama,mau menjawab salam, klien mau duduk berdampingan dengan perwat, mau mengutarakanmasalah yang dihadapi. Rencana tindakan. Bina hubungan saling percaya dengan mengungkapkan prinsip komunikasi teraupetik yaitu sapa klien dengan ramah baik verbal maupun non verbal, perkenalkan diri dengan sopan, tanyakan nama lengkap kliendan nama panggilanyang disukai klien, jelaskan tujuan pertemuan, jujur dan menepati janji, tunjukkan sikap empati dan menerima klien apa adanya, serta beri perhatian kepeda klien dan perhatikan kebutuhan dasar klien.

TUK II :Klien dapat mengidentifikasi kemampuan dan aspek positip yang dimiliki klien. Kriteria Evaluasi : Klien mengidentifikasi kemampuan dan aspek positif yang dimiliki : Kemampuan yang dimiliki klien, Aspek positif keluarga, serta Aspek positif lingkungan yang dimiliki klein 
Rencana Tindakan : Diskusikan kemempuandan aspek positif yang dimiliki klien, Setiap bertemu klien di hindarkan dari memberi penilaian negative, serta Utamakan member pujian yang realistic

TUK III : Klien dapat menilai kemampuan yang digunakan. Kriteria Evaluasi :Klien menilai kemampuan yang dapat digunakan adalah Diskusikan dengan klien kemampuan yang masih dapat digunakan selama sakit, dan Diskusikan kemampuan yang dapat dilanjutkan penggunaan sesuai dengan kemampuan yang dimiliki. Kriteria Evaluasi :Klien membuat rencana kegiatan sehari-hari

Rencana Tindakan : Rencanakan bersama klien aktivitas yang dapat dilakukan setiap hari sesui kemampuan: Kegiatan mandiri, Kegiatan dengan bantuan sebagian, dan kegiatan yang membutuhkan bantuan total, Tingkatkan kegiatan sesuai dengan toleransi kondisi klien, serta Beri contoh cara pelaksanaan kegiatan yang boleh klien lakukan

TUK V : Klien dapat melakukankegiatan sesui kondisi sakit dan kemampuannya. Kriteria Evaluasi : Klien melakukan kegiatan sesui kondisisakit dan kemampuannya

Rencana Tindakan : Beri kesempatan pada klien untuk mencoba kegiatan yang telah direncanakan, dan Beri pujian atas keberhasilan klien, serta Diskusikan kemungkinan pelaksanaan di rumah

TUK VI : Klien dapat memanfaatkan sistem pendukung yang ada. Kriteria Evaluasi :Klien memanfaatkan sistem pendukung yang ada di keluarga

Rencana Tindakan : Beri pendidikan kesehatan pada keluarga tentang cara merawat klien dengan hargadiri rendah, Bantu keluarga memberikan dukungan selama klien dirawat, serta Bantu keluarga menyiapkan lingkungan di rumah

\section{PEMBAHASAN}

\section{Pengkajian}

Pada pengkajian, penulis memfokuskan pada faktor predisposisi, faktor presipitasi, manifestasi klinis, dan tes diagnostik. Berdasarkan faktor predisposisi pada teori ada 4 bagian yaitu faktor perkembangan, faktor komunikasi dalam keluarga, faktor sosial budaya dan faktor biologis. Menurut teori dari hasil predisposisi dan faktor presipitasi dibandingkan dengan kasus Tn.D adalah klien sebelumnya pernah bersekolah hingga SD, dan klien tidak melanjutkan sekolah karena keluarga klien tidak mampu untuk membiayai sekolahnya. Karena itu klien merasa malu, lebih banyak diam, selalu menyendiri dan tidak mau bergaul dengan orang lain.

Pada tahap pengkajian tidak ditemukan faktor genetik dalam keluarga klien, klien masuk Rumah Sakit Jiwa untuk yang kedua kalinya, pertama pada bulan mei tanggal 292008 sampa bulan juli tanggal 03 di Rumah sakit Dr soeharto herjan juga dan yang kedua pada bulan Mei tanggal 262010 sampai saat ini. Disini dapat dilihat bahwa pengobatan sebelumnya kurang berhasil karena kurangnya komunikasi keluarga dalam memberikan dukungan dan perhatian. 
Dan sebagai perbandingan antara teori dan kasus yaitu analisa faktor penghambat dan faktor pendukung penulis menemukan hambatan yaitu tidak dapat bertemu dengan keluarga klien, sehingga menyulitkan penulis untuk memvalidasi antara data yang didapat dari klien dengan penjelasan keluarga dan keadaan klien yang berfluktuasi mengisolasi diri. Tetapi penulis berusaha mengatasinya dengan bertanya kepada perawat ruangan, membaca laporan harian, serta melakukan pendekatan pada klien dengan pendekatan komunikasi terapeutik. Sedangkan faktor pendukungnya adalah telah tersedianya format pengkajian sehingga memudahkan penulis untuk mencari data dengan cepat pada klien, selain itu adanya kerja sama yang baik dengan perawat dalam memberikan informasi tentang klien.

Pada pohon maslah terjadi kesenjangan antara teori dan kasus. Dalam teori terdapat 3 masalah keperawatan yaitu Isolasi Sosial, Harga Diri Rendah. Resiko gangguan sensori persepsi halusinasi Sedangkan dalam kasus ini terdapat 5 masalah keperawatan yaitu : Isolasi Sosial, Harga Diri Rendah, koping keluarga in efektip, Regimen Terapeutik inefektif, dan resiko gangguan sensori persepsi halusinasi.

\section{Diagnosa Keperawatan}

Pada diagnosa keperawatan ditemukan 2 diagnosa yang berbeda dengan teori yaitu koping keluarga inefektip dan regimen tharapetik inefektip. Data pada diagnosa koping keluarga inefektip didapat dari pengkajian yaitu , keterangan perawat, serta menanyakan pada klien, bahwa klurga klien blm pernah datang untuk menjenguk klien Sedangkan pada Diagnosa kedua, Regimen Terapeutik Inefekt didapat data pada pengkajian dari status, keterangan perawat serta menanyakan pada klien, bahwa klien pernah dirawat 2 kali, yang pertama pada bulan mei 2008 di Rumah Sakit Dr. Soeharto herdjan juga dan yang kedua pada bulan Mei 2010 tanggal 26 sampai saat ini. Hambatannya yaitu tidak dapat bertemu dengan keluarga klien dikarenakan keterbatasan waktu dalam praktek keperawatan dan waktu kunjungan keluarga klien tidak tentu

\section{Perencanaan Keperawatan}

Di dalam perencanaan penulis menyusun sesuai perencanaan keperawatan yang ada didalam teori yaitu ditetapkan berdasarkan prioritas masalah, tujuan, kriteria evaluasi, rencana keperawatan yang dapat diukur.

Diagnosa yang utama adalah Isolasi Sosial, sehingga diagnosa keperawatan tersebut yang harus dintervensi, pada pasien adapun rencana yang dilakukan adalah SP I : bina hubungan saling percaya, Identifikasi penyebab Isolasi Sosial, Diskusikan dengan klien tentang keuntungan berinteraksi dengan orang lain, diskusikan dengan klien tentang kerugian tidak berinteraksi dengan orang lain, ajarkan klien tentang cara berkenalan, beri pujian terhadap kemampuan yang dilakukan klien, anjurkan pasien memasukkan kegiatan latihan berbincang - bincang dengan orang lain dalam kegiatan harian, SP II : evaluasi jadwal kegiatan harian klien, anjurkan untuk mempraktekkan cara berkenalan dengan perawat lain, SP III : evaluasi kegiatan harian klien, anjurkan untuk mempraktekkan cara berkenalan dengan orang lain (teman klien). Pada keluarga yaitu Sp-I diskusikan masalah yang dirasakan keluarga dalam merawat pasien, jelaskan pengertian, tanda dan gejala Isolasi Sosial, Sp:II melatih keluarga memperakktekkan cara merawat pasien dengan Isolasi Sosial, SpIII; Membantu keluarga membuat jadwal aktivitas di rumah termasuk minum obat.

Dan untuk diagnose ke 2 penulis merencanakan SP I: mengidentifikasi kemampuan dan aspek positif yang di miliki klien ,bantu pasien menilai kemampuan yang masih bisa di gunakan,membantu pasien memilih kegiatan yang akan di latih sesuai dengan kemampuan 
pasien, melatih pasien sesuai kemampuan yang dipilih, memberi pujian yang wajar terhadap keberhasilan pasien,menganjurkan pasien memasukkan ke dalam jadwal kegiatan harian, SP II : mengevaluasi jadwal kegiatan harian pasien, melatih kemampuan ke dua,menganjurkan pasien memasukkan ke dalam jadwal kegiatan harian.

Kemudian untuk keluarga SP I : diskusikan masalah yang dirasakan keluarga dalam merawat pasien, menjelaskan pengertian tanda dan gejala harga diri rendah yang di alami pasien serta proses terjadinya, menjelaskan cara merawat pasien harga diri rendah. SP II : melatih keluarga mempraktekkan cara merawat pasien dengan harga diri rendah, SP III : membantu keluarga membuat jadwal aktivitas di rumah termasuk minum obat, menjelaskan follow up pasien setelah pulang. Factor pendukung didalam perencanaan ini adalah penulis dapat membuat perencanaan sesuai dengan literature dan pedoman yang sudah ada serta adanya bimbingan dosen Akademik. Dalam factor penghambat penulis tidak menemukan hambatan dalam membuat perencanaan.

\section{Pelaksanaan Keperawatan}

Dalam melaksanakan tindakan keperawatan penulis mengacu pada rencana tindakan keperawatan yang telah ditetapkan seluruhnya dan disesuaikan dengan kondisi klien saat ini. Penulis mengimplementasikan 1 diagnosa saja, yaitu Isolasi Sosial. Untuk Isolasi Sosial yaitu : pada hari pertama melakukan sp1 dengan cara membina hubungan saling percaya antara perawat dan klien, mengidentifikasikan penyebab Isolasi Sosial Pasien, mendiskusikan dengan klien keuntungan berinteraksi dengan orang lain dan kerugian tidak berinteraksi dengan orang lain, mengajarkan cara berkenalan, memberikan kesempatan pada klien untuk mempraktekkan cara berkenalan dengan orang lain, menganjurkan klien memasukkan kegiatan kedalam jadwal harian.

Kemudian pada hari kedua melakukan sp II dengan cara Evaluasi jadwal kegiatan harian pasien Berikan kesempatan kepada pasien mempraktekkan cara berkenalan dengan satu orang Bantu pasien memasukkan kegiatan berbincang-bincang dengan orang lain sebagai salah satu kegiatan harian.klien,Melakukan Sp III yaitu, mengevaluasi jadwal kegiatan harian pasien, memberikan kesempatan pada pasien untuk memperaktekkan cara berkenalan dengan dua orang atau lebih, membantu pasien untuk memasukkan kegiatan yang sudah di lakukan yaitu berkenalan dengan dua orang atau lebih ke dalam jadwal kegiatan harian, meskipun di teori klien Isolasi Sosisl tidak mendapat terapi obat tapi di lapangan pasien mendapat terapi obat yaitu Halopenidol (5mg) 3x $1 \frac{1}{2} 2$ tablet, Trihexypenidyl (2 mg) 3 x 1 tablet, Chlopromazine $(100 \mathrm{mg}) 1 \mathrm{x} 1$ tablet, Amitriptyline $(100 \mathrm{mg}) 1 \mathrm{x} 1$ tablet. Yaitu untuk mengobati fisik klien dan menghilangkan sresor klien, dan Obat itu diberikan sesuai dengan keadaan pasien. Untuk diagnosa harga diri rendah, koping keluarga inefektif, regimen therapetik in efektifi,dan resiko gangguan persepsi halusinasi tidak dilakukan. Adapun factor pendukung klien kooperatif sehingga penulis dapat melakukan interaksi sesuai dengan yang diharapkan.

Pada implementasi ini terdapat kesenjangn antara teori dan kasus yaitu pada teori kasus tidak mendapat terapi obat sedangkan pada kasus mendapat terapi obat. Factor penghambat yang penulis temukan yaitu penulis tidak dapat bertemu dengan keluarga, sehingga intervensi pada keluarga tidak dapat dilakukan dikarenakan waktu keluarga besuk tidak menentu,dan waktu pelaksanaan asuhan 
5. Evaluasi

Evaluasi merupakan tahap akhir dalam asuhan keperawatan, didalam evaluasi penulis melakukan observasi terhadap respon klien mengenai tindakan keperawatan dan didokumentasikan pada catatan keperawatan dan evaluasi dilakukan untuk menilai sejauh mana keberhasilan tindakan yang telah dilakukan.

Pada diagnosa keperawatan utama yaitu Isolasi Sosial klien dapat membina hubungan saling percaya dengan perawat, klien sudah mempraktekkan cara berkenalan dengan satu orang, klien sudah memperaktekkan cara berkenalan dengan dua orang, dan memasukkan ke dalam jadwal kegiatan harian. Faktor pendukung klien kooperatif dan serta bantuan dari perawat ruangan untuk membantu menulis dan melaksanakan evaluasi. Factor penghambat yang penulis temukan yaitu penulis tidak dapat bertemu dengan keluarga, sehingga intervensi pada keluarga tidak dapat dilakukan dikarenakan waktu keluarga besuk tidak menentu,dan waktu pelaksanaan yang terbatas.

\section{KESIMPULAN}

Implementasi yang dilakukan yaitu : Isolasi Sosial dengan cara : Sp I membina hubungan saling percaya antara perawat dan klien, mengidentifikasikan penyebab Isolasi Sosial Pasien, mendiskusikan dengan klien keuntungan berinteraksi dengan orang lain dan kerugian tidak berinteraksi dengan orang lain, mengajarkan cara berkenalan, Sp II yaitu memberikan kesempatan pada klien untuk mempraktekkan cara berkenalan dengan satu orang, menganjurkan klien memasukkan kegiatan kedalam jadwal harian. Sp III yaitu memberikan kesempatan pada klien untuk memperaktekkan cara berkenalan dengan dua orang atau lebih, memasukkan kegiatan yang dilakukan kedalam jadwal kegiatan harian.

Evaluasi yang dapat dicapai dari hasil tindakan keperawatan adalah hubungan saling percaya antara perawat dan klien, klien dapat dapat menyebutkan penyebab Isolasi Sosial, menyebutkan keuntungan berinteraksi dengan orang lain dan kerugian tidak berinteraksi dengan orang lain. Klien dapat mempraktekkan cara berkenalan dengan satu orang. Klien dapat memperaktekkan cara berkenalan dengan dua orang, klien dapat memasukkan kegiatan kedalam jadwal harian apa yang sudah diajarkan dan dilakukan.

\section{DAFTAR PUSTAKA}

[1] Carpenito, Lynda Juall, (2000). Buku Saku Diagnosa Keperawatan, Edisi 6. Jakarta: EGC.

[2] Departemen Kesehatan Republik Indonesia, (2000). Pedoman Keperawatan Jiwa. RSJP. Bandung

[3] Keliat, Budi Ana, (2005), Proses Keperawatan Kesehatan Jiwa, Jakarta : Penerbit Buku. Kedokteran EGC.

[4] Maramis W.F (2004). Ilmu Kedokteran Jiwa. Airlangga University Press, Surabaya

[5] Stuart, Gail. W. 2006. Buku Saku Keperawatan Jiwa, Edisi 5, Jakarta : EGC 